\title{
PATRIMÔNIO NATURAL EM CONTEXTO URBANO: A GESTÃO DA CONSERVAÇÃO DO PARQUE DOS MANGUEZAIS, RECIFE-PE.
}

\author{
NATURAL HERITAGE IN URBAN CONTEXT: \\ THE CONSERVATION MANAGEMENT OF THE PARQUE DOS MANGUEZAIS, RECIFE-PE.
}

\author{
Célio Henrique Rocha Moura \\ Onilda Gomes Bezerra \\ Tomás de Albuquerque Lapa \\ Caio Coelho Silva Albuquerque
}

\begin{abstract}
RESUMO
O presente artigo tem como objetivo a identificação dos valores patrimoniais do Parque dos Manguezais (Unidade de Conservação do Recife) que representam a significância natural do bem e que consiste na etapa inicial do processo de conservação patrimonial, de acordo com a Australian Natural Heritage Charter (IUCN, 2002). Para identificação dos valores, foram entrevistadas distintas categorias de atores (moradores do entorno, especialistas e agentes públicos), cujos depoimentos foram analisados com base no método Análise de Conteúdo. Como resultado, foram estabelecidas as dimensões patrimoniais relacionadas aos aspectos ecológicos e culturais da Unidade de Conservação, assim como foram levadas em consideração as inter-relações que tais atores mantêm com o ecossistema e que sinalizam as ações objetivas de conservação do Parque dos Manguezais.
\end{abstract}

Palavras-Chave: Patrimônio Cultural. Patrimônio Natural. Unidades de Conservação. Parque dos Manguezais. Valores Patrimoniais.

\section{ABStRACt}

This article aims at the heritage values' identification of the Parque dos Manguezais (Recife's Conservation Unit) which represents its natural significance and consists of the initial stages in the heritage conservation's process, according to the Australian Natural Heritage Charter (IUCN, 2002). For the values identification, distinct actor categories were interviewed surrounding residents, specialists, public agents), whose testimonies were analyzed based on content analysis method. As result, there were established heritage dimensions related to the Conservation Units' ecological and cultural aspects, as well as the interrelations that actors maintain with the ecosystem that signal the objective actions of conservation of the Parque dos Manguezais' were considered.

Keywords: Cultural Heritage. Natural Heritage. Conversation Units. Parque dos Manguezais. Heritage Values. 


\section{INTRODUÇÃO}

O processo de exploração dos recursos naturais, sobretudo da Mata Atlântica, aliado ao crescimento industrial e urbano do país, intensificado no século $X X$, causaram grandes rupturas nesse Bioma, até transformá-lo em uma série de fragmentos de florestas, muitos dos quais, atualmente, são esparsos e sem conexão. De acordo com o relatório anual da fundação SOS Mata Atlântica de 2017 , restava um total de $12,4 \%$ de sua cobertura original no território brasileiro, enquanto nos anos de 2018 a 2019, o bioma apresentou uma taxa crescente de desmatamento de $27,2 \%$, representando a maior taxa desde o ano de 2016, conforme exposto no Atlas dos Remanescentes Florestais da Mata Atlântica de 2018-2019 (INPE e Fundação SOS Mata Atlântica).

Ao bioma da Mata Atlântica está associado o ecossistema de manguezal, que atua como uma das zonas mais produtivas do mundo. De acordo com o Atlas dos Manguezais do Brasil (ICMBIO, 2018), sua importância é fundamental para a manutenção de bens e serviços ecossistêmicos, bem como para o crescimento e sobrevivência dos animais de vida marinha em seus estágios iniciais. Além disso, os manguezais desempenham um importante papel para a subsistência de comunidades de pescadores que se estabelecem nas proximidades (ICMBIO, 2018a).

Segundo a mesma fonte, as atividades antrópicas em área costeira, o desenvolvimento industrial e o crescimento populacional sobre os mananciais representam um dos maiores riscos aos manguezais. Tal situação se acentua em áreas urbanas, onde a pressão antrópica acarretou, nas últimas décadas, em uma grave degradação desses ecossistemas, ampliando-se em decorrência de um planejamento urbano inadequado, do assoreamento, da poluição representada pelos resíduos sólidos e líquidos e dos aterros irregulares, dentre outros fatores (MELO, 2014). Para exemplificar quantitativamente a supressão do ecossistema de manguezais, estima-se que aproximadamente $25 \%$ do ecossistema tenha se perdido no país em decorrência de atividades antrópicas (ICMBIO, 2018a).
A preservação da natureza, e em especial a dos manguezais, está diretamente ligada às dinâmicas da relação entre o homem e o meio em que vive. Para além dos atributos naturais de importância ecológica, a dimensão patrimonial de tais ecossistemas se amplia, assim como as dimensões relacionadas às populações ribeirinhas, notadamente seus modos de vida e suas marcas identitárias.

No caso específico da cidade do Recife, o manguezal constitui um ecossistema singular que referencia a identidade cultural e natural pulsante na cidade. Segundo Bezerra (2017), no século XVI, o território se apresentava como um delta assoreado pela ação dos rios, caracterizando-se como um ambiente estuarino, ora composto por água, ora charco e ora por vegetação adaptada. Assim, os manguezais representam verdadeiros sítios histórico-fisiográficos da cidade, reflexo da paisagem originária podendo, portanto, ser reconhecidos como patrimônio natural, que, de acordo com a Carta do Patrimônio Natural da Austrália' ${ }^{1}$, significam sítios, áreas naturais, formações fisiográficas ou recursos naturais que demonstram significância natural ${ }^{2}$, ou seja, são reconhecidos por uma gama de valores cuja importância se irradia para as gerações presentes e futuras (IUCN, 2002).

O objeto empírico de estudo, que corresponde ao Parque dos Manguezais, constitui uma Unidade de Conservação Municipal localizada na cidade do Recife, aparecendo como um dos mais representativos fragmentos de manguezal da urbe. A essa Unidade de Conservação estão associadas comunidades pesqueiras, cuja atividade é desenvolvida localmente desde os primórdios da ocupação do território, primordialmente por ex-escravizados foragidos (SILVA et al., 2016).

\footnotetext{
1 Australian Natural Heritage Charter (IUCN, 2002)
}

2 Natural Heritage means: - natural features consisting of physical and biological formations or groups of such formations, which demonstrate natural significance - geological and physiographical formations and precisely delineated areas that constitute the habitat of indigenous species of animals and plants, which demonstrate natural significance, and/or - natural sites or precisely-delineated natural areas which demonstrate natural significance from the point of view of science, conservation or natural beauty (IUCN, 20002, p. 8). 
Do ponto de vista patrimonial, as relações estabelecidas entre as comunidades e o ambiente natural representam um registro identitário e histórico que, além do significado natural intrínseco, confere ao sítio um significado cultural. Por sua vez, tal significado é definido pela Carta de Burra ${ }^{3}$ como sendo um conjunto amplo de valores estético, social, científico e histórico de natureza antrópica (ICOMOS, 2013). Além disso, o Parque dos Manguezais apresenta atributos naturais singulares, incluindo espécies nativas de Mata Atlântica, tais como a Rizophora mangle e a Aviccenia schaueriana (o mangue-vermelho e o mangue-preto, respectivamente), ameaçadas de extinção, de acordo com a IUCN Red List of Threatened Species ${ }^{4}$ (2018). Tais atributos naturais e culturais denotam a singularidade do ecossistema, o que suscita um processo de gestão com uma abordagem específica, cujo objetivo é identificar a dimensão patrimonial com amplo escopo de tratamento, sobretudo frente aos riscos a que está submetido esse ecossistema no contexto urbano.

No ano de 2018, em uma tentativa de conter as pressões antrópicas que põem em risco a preservação das Unidades de Conservação, a Prefeitura do Recife deu início à elaboração dos Planos de Manejo Municipais para as unidades situadas no território da cidade, dentre as quais o Parque dos Manguezais. Contudo, na gestão do patrimônio natural, vale destacar que os planos específicos devem ser elaborados amparando-se na sua significância. Nesse sentido, os planos de manejo não atuam de forma efetiva enquanto planos de gestão da conservação, que por sua vez caracterizam-se por ser um pacto político entre os atores comprometidos com o bem que, ao norte fundamental da significância, atuam na conservação dos seus valores patrimoniais. Segundo De La Mora (2012), a gestão da conservação do patrimônio é uma especialidade da gestão pública voltada para a implementação de projetos, políticas ou programas destinados à proteção do patrimônio, em conformidade com outras dimensões do desenvolvimento urbano. Essa perspectiva deve ser levada em consideração, principalmente no contexto das grandes cidades. Em se tratando de conservação patrimonial, as ações tradicionalmente

3 Burra Charter (ICOMOS, 2013)

4 Lista Vermelha de Espécies Ameaçadas da IUCN adotadas por gestões públicas ou privadas locais, sob a ótica do suprimento de demandas imediatas ou estruturais das cidades ou atores específicos, representam um risco aos valores patrimoniais de determinados bens.

A gestão da conservação patrimonial deve buscar, portanto, conciliar os interesses urbanos com a conservação do bem (DE LA MORA, 2012). No complexo processo de gestão do território urbano, as ações tradicionais de gestão e as ações de Gestão da Conservação Patrimonial não necessariamente devem estar dissociadas. Movidas pelo interesse comum de desenvolvimento urbano e social, no planejamento urbano, determinadas ações devem ser conjuntas ou complementares.

No que tange ao Parque dos Manguezais, urge a necessidade de compreensão da sua significância natural e cultural, representada pelos valores patrimoniais que, por sua vez, são conferidos por atores específicos relacionados com o bem. Em todas as etapas de compreensão da sua dimensão patrimonial, assim como na elaboração de planos de gestão estratégicos, é imprescindível considerar os distintos atores no processo de identificação dos valores patrimoniais. Para tanto, De La Mora (2012) destaca que é necessário compreender seus interesses e formar parcerias estratégicas locais. Assim, neste artigo, busca-se trazer à tona a discussão sobre a importância dos valores patrimoniais do Parque dos Manguezais, com foco nos atores envolvidos com o bem, cuja inter-relação poderá nortear um arcabouço teórico-metodológico para elaboração dos futuros Planos de Manejo do Parque dos Manguezais, assim como de outras Unidades de Conservação inseridas em contexto urbano.

\section{Metodologia}

O objeto do presente estudo, Parque dos Manguezais, foi compreendido com base em sua caracterização fisiográfica e institucional, bem como na identificação dos principais atores que com ele mantêm relações significativas, atribuindo-lhe valores que revelam sua significância. Por meio dos itens a seguir, serão descritas as etapas do processo metodológico de apreensão dos 
valores, partindo da compreensão do objeto de estudo, dos atores entrevistados e do procedimento e análise de dados, que têm por base o método de Análise de Conteúdo.

\subsection{O objeto de estudo: O Parque dos MANGUezaIS}

Do ponto de vista físico-institucional, o Parque dos Manguezais fica localizado na Zona Sul do Recife, no bairro do Pina, componente da $6^{a}$ Região Político-Administrativa da cidade. Constitui-se como um fragmento de ecossistema estuarino, inserido no contexto urbano, correspondendo a 320,24 Ha (Figura 1).

A área, de propriedade da Marinha do Brasil, foi reconhecida como Zona Especial de Proteção Ambiental - ZEPA, pela Lei de
Uso e Ocupação do Solo - LUOS (Lei Municipal n. 16.176, de 9 de abril de 1996). Em seguida, essa classificação foi alterada pelo Plano Diretor da Cidade do Recife (Lei Municipal n. 17.511, de 29 de dezembro de 2008), sendo designada como Unidade Protegida. Por meio do Decreto Municipal n. 25.565, de 1 de dezembro de 2010, foi declarada Unidade de Conservação da Natureza, na categoria de Parque Natural Municipal, incluída no Grupo de Proteção Integral, em conformidade com o SNUC - Sistema Nacional de Unidades de Conservação.

Atualmente, configura-se como Unidade de Conservação em nível municipal, reconhecida pelo Sistema Municipal de Unidades Protegidas - SMUP, com base na Lei Municipal n. 18.014/2014, sendo margeada pela Zona Especial de Interesse Social - ZEIS Pina/Encanta-Moça, conforme Figura 2.

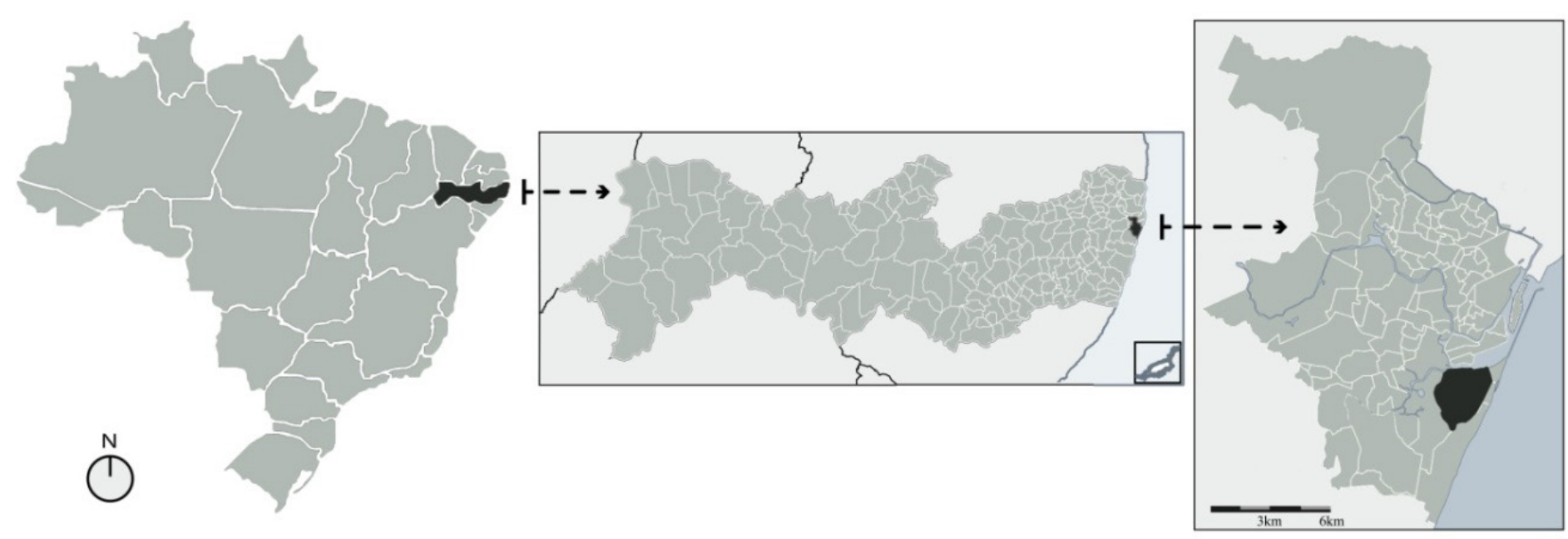

Figura 1 - Mapa de localização do objeto de estudo. Fonte: Elaboração dos autores, 2020. 

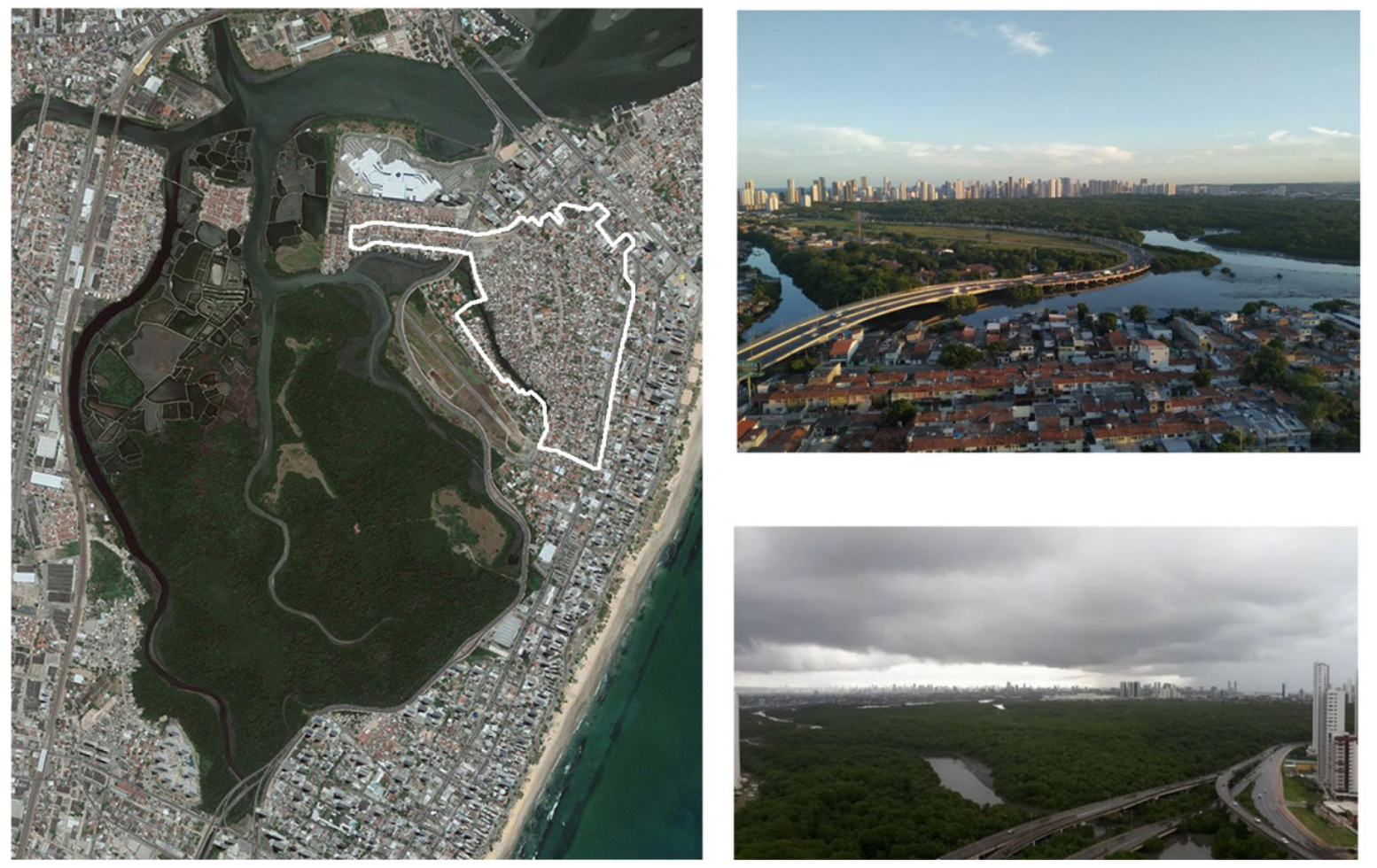

Figura 2 - Mapa da Unidade de Conservação Parque dos Manguezais. Marcação em branco: delimitação da ZEIS Pina/Encanta-Moça. Fonte: Elaboração dos autores sobre imagem satélite Google, 2020;

Fotos: Parque dos Manguezais.

Fonte: Acervo dos autores, 2019

\subsection{Principais atores relacionados ao Parque dos Manguezals}

O entendimento da significância do bem patrimonial deve passar por um processo de validação social dos valores. Segundo Zancheti et al. (2008, apud Ribeiro e Lira, 2011, p. 39), a significância é o conjunto de valores que resultam da validação social dos significados passados e presentes do bem. Os autores enfatizam que tal julgamento, realizado no presente, tem como referência os valores destacados do passado, desde que haja validação atual pela sociedade. Citando o processo de validação da significância cultural, Ribeiro e Lira (2011) reiteram a consideração de Zancheti, destacando que:

Por meio da participação de diversos grupos ou comunidades, existe a necessidade de que em seu processo de construção haja uma validação social. Por conta disso, esse processo não é linear. Nele podem ocorrer algumas idas e vindas até que essa validação ocorra (p. 40).

O destaque dado ao conjunto de atores no processo de valoração de um bem repercute na construção dos procedimentos de Gestão da Conservação Patrimonial, cujas políticas estratégicas devem levar em consideração os valores atribuídos pelos atores que participam dessa complexa dinâmica (MOURA, et al., 2018). Assim, para o reconhecimento patrimonial, deve anteceder a identificação dos valores que Ihe são atribuídos pelos mais diversos atores, os quais evocam sua significância.

Para identificação dos valores patrimoniais do Parque dos Manguezais, foram selecionadas quatro categorias de atores junto às quais foram aplicadas entrevistas semi-estruturadas durante o período de levantamento do material de análise desta investigação (janeiro a maio de 2019). Cada grupo foi definido de acordo 
com o vínculo que possui com o Parque dos Manguezais e seu entorno urbano, desde os que mantêm uma relação direta de subsistência ou usufruto com esse meio natural, até os que possuem uma relação indireta, tais como pesquisadores, ambientalistas, técnicos ou gestores/agentes públicos, caracterizados a seguir:

\section{Categoria 1 e 2 - Moradores}

No total, foram entrevistadas 18 pessoas, dentre as quais 12 moradores da ZEIS Pina/Encanta-Moça, e 6 moradores dos edifícios de classe média, estabelecidos no entorno da Unidade de Conservação. A delimitação da área de aplicação das entrevistas junto a moradores locais tomou como base a delimitação territorial da ZEIS Pina/Encanta-Moça, incluindo os edifícios residenciais de classe média recentemente construídos no entorno, a contar do ano de 2002 até os dias atuais.

\section{Categoria 3 - Especialistas}

Foram identificados indivíduos com diferentes ramos de atuação profissional, mas que tinham em comum uma relação de trabalho ou pesquisa com o objeto de estudo. Dessa forma, foram entrevistados pesquisadores de Grupos e Institutos de Pesquisa, bem como docentes universitários, totalizando um conjunto de 6 atores.

\section{Categoria 4 - Gestores ou Agentes Públicos}

Para esse grupo, foram entrevistados um total de 4 técnicos que fazem parte do corpo do funcionalismo público municipal ou estatal, tendo em vista seu papel no sistema de gestão patrimonial, que é fundamental para o processo de conservação do ecossistema.

\subsection{A AnÁlise de dados}

O procedimento de estudo e interpretação das expressões orais levantadas nas entrevistas se deu, primariamente, por meio da transcrição literal de todo material de áudio obtido. Em seguida, foi realizada a aplicação do método "Análise de Conteúdo", cujos princípios são aplicados para análise documental e de outros elementos textuais. Segundo Bardin (1977), por meio da análise documental, se consegue uma segunda representação do documento que passa de seu estado bruto para uma condensação representativa. Por meio desse método, também se alcança a indexação que permite a transposição do sentido do elemento textual para palavras-chave (BARDIN, 1977).

Para a identificação dos valores patrimoniais conferidos pelos atores entrevistados, foram destacadas das entrevistas certas qualidades ou atributos relacionados ao Parque dos Manguezais. Tais atributos estavam inseridos em uma unidade de contexto específica, cuja análise é primordial para o entendimento do sentido das falas dos atores. Por fim, os atributos foram agrupados em categorias, de acordo com sua semelhança semântica de modo que, amparados na base conceitual específica, funcionarão como referência para os valores patrimoniais, conforme o seguinte esquema (Figura 3).

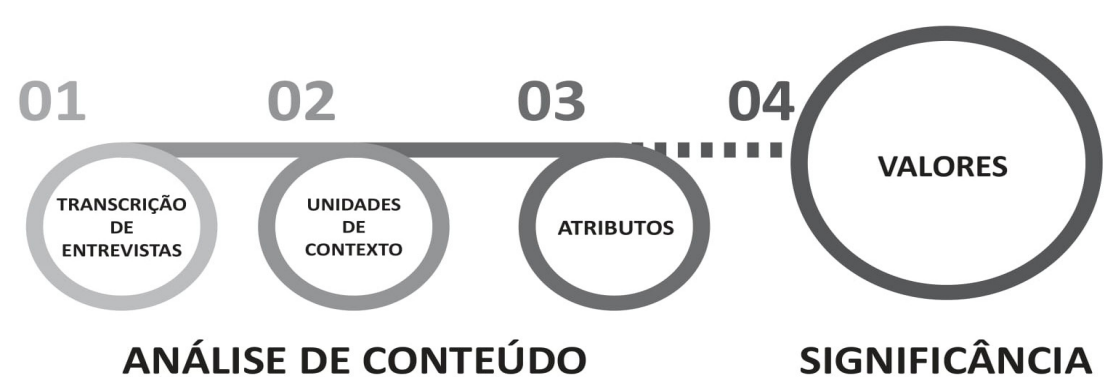

Figura 3 - Esquema metodológico da Análise de Conteúdo. Fonte: Elaboração dos autores. 
Mediante o procedimento metodológico acima descrito, foi possível identificar dez principais valores patrimoniais atribuídos pelos atores entrevistados: Biodiversidade, Geodiversidade, Ecológico, Valor de Opção, Científico, Social, Estético, Polissensorial, Cultural e Espiritual.

\section{Resultados e Discussões}

A noção de significância está relacionada à apreensão dos valores patrimoniais de um bem, tendo em vista a identificação dos atores que com ele estão relacionados ou interessados na sua conservação (IUCN, 2002; ICOMOS, 2013). Assim, a discussão centrada nos atores é fundamentada nos valores patrimoniais conferidos coletivamente ao bem analisado.

No caso do Parque dos Manguezais, os valores são conferidos a partir da apreensão dos atributos naturais e culturais, sendo os primeiros relacionados ao valor de existência e os segundos aos valores de natureza antrópica. Bezerra (2011) afirma que há um reconhecimento cada vez maior do Patrimônio Natural por seus valores híbridos, fruto das suas características naturais e das expressões humanas nele gravadas historicamente. Assim, um lugar pode apresentar valores tipicamente naturais e/ou tipicamente culturais. Contudo, as imbricadas relações sociais entre o homem e o meio natural, muitas vezes, tornam indissociáveis os atributos naturais e culturais, resultando nos valores patrimoniais híbridos. Segundo a Carta do Patrimônio Natural da Austrália, as comunidades tradicionais geralmente tendem a não enxergar tais valores separadamente (IUCN, 2002).

De acordo com os depoimentos dos atores entrevistados, os valores patrimoniais do Parque dos Manguezais subdividem-se em: valores tipicamente naturais: de Biodiversidade, de Geodiversidade e Ecológico; valores tipicamente culturais: Polissensorial, Cultural, Espiritual e valores híbridos (natural e cultural): de Opção, Científico, Social e Estético. A Tabela 1 ressalta todos os valores conferidos pelos atores entrevistados, bem como sua definição:

\begin{tabular}{l|l}
\hline VALORES NATURAIS & \multicolumn{2}{l}{$\begin{array}{l}\text { De Biodiversidade } \\
\text { telacionados com "a variabilidade entre os organismos vivos de todas as origens (incluindo os ecossistemas } \\
\text { (IUCN, 2002, art. 1.5, p. 9). }\end{array}$} \\
\hline De Geodiversidade & $\begin{array}{l}\text { Identificados por meio da valoração dos atributos físicos não-vivos presentes no ecossistema, como aqueles } \\
\text { que representam "evidências da vida passada, dos ecossistemas e dos ambientes na história da terra, bem } \\
\text { como uma variedade de processos atmosféricos, hidrológicos e biológicos atuando em rochas, formas de } \\
\text { relevo e solos" (IUCN, 2002, art. 1.4, p. 9). }\end{array}$ \\
\hline Ecológico & $\begin{array}{l}\text { Determinados pela compreensão do conceito de ecossistema que se caracteriza como um "complexo dinâ- } \\
\text { mico de organismos e seu ambiente não-vivo, interagindo como uma unidade funcional" (IUCN, 2002, art. } \\
\text { 1.14, p. 10). }\end{array}$ \\
\hline VALORES HÍBRIDOS & $\begin{array}{l}\text { Remetem à possibilidade de utilização futura do próprio bem. "Em outras palavras, o bem patrimonial } \\
\text { pode não estar gerando utilidades no presente, mas pode gerar benefício no futuro" (LACERDA, 2012, p. } \\
51) .\end{array}$ \\
\hline De Opção &
\end{tabular}




\begin{tabular}{l|l}
\hline Científico & $\begin{array}{l}\text { Caracterizam-se pelo potencial que apresentam para a realização de pesquisas e educação patrimonial, } \\
\text { conhecimento fundamental para identificação da Significância Natural e Cultural do Bem Patrimonial, de } \\
\text { acordo com a Carta de Burra e do Patrimônio Natural da Austrália. }\end{array}$ \\
\hline Social & $\begin{array}{l}\text { São conferidos ao se admitir a evidência e a importância de atividades sociais atreladas à existência do } \\
\text { ecossistema. Tais atividades reforçam o caráter cultural, atrelado ao Patrimônio Natural, o que aponta para } \\
\text { sua Significância Cultural (ICOMOS, 2013, art. 1.2, p. 2). }\end{array}$ \\
\hline Estético & $\begin{array}{l}\text { Compreendem a valoração dos atributos relacionados aos aspectos cênicos, apreendidos pelos atores inter } \\
\text {-relacionados com o meio onde o bem se insere. }\end{array}$ \\
\hline VALORES CULTURAIS & $\begin{array}{l}\text { São caracterizados pela valorização das percepções sensoriais destacadas pelos atores entrevistados, em } \\
\text { relação à sensação física humana frente à natureza, que aguçam os sentidos olfativa, visual, auditiva, tátil } \\
\text { ou espiritualmente. }\end{array}$ \\
\hline Cultural & $\begin{array}{l}\text { Remetem à condição do ecossistema, em relação aos elementos culturalmente edificados e associados en- } \\
\text { quanto registro histórico ou "enquanto revelação de uma época, de seus modos de vida" (LACERDA, 2012, } \\
\text { p. 47). }\end{array}$ \\
\hline Espiritual & $\begin{array}{l}\text { São fruto da interpretação etérea da natureza que, segundo Diegues (1996), sempre esteve associada ao } \\
\text { universo mítico do ser humano e sua relação com os ciclos naturais. }\end{array}$ \\
\hline
\end{tabular}

Tabela 1: Descrição dos valores patrimoniais do Parque dos Manguezais. Fonte: Elaboração dos autores.

A identificação dos valores é fundamental para a compreensão da significância do patrimônio. Para isso, é imprescindível que os grupos investigados estejam direta ou indiretamente ligados aos processos sociais e culturais que envolvem o bem patrimonial analisado, considerando que tais atores são peças-chave no processo de avaliação do bem. De acordo com Bezerra (2011), os valores patrimoniais são aqueles reconhecidos pelos agentes envolvidos no processo de proteção do bem, que podem ser técnico-científicos, político-econômicos, grupos sociais ou ainda as comunidades correlacionadas ao objeto de avaliação. Assim, apresenta-se a seguir a discussão sobre como cada categoria de atores entrevistada confere os valores patrimoniais ao Parque dos Manguezais, quantificando por meio de gráficos a recorrência em que os atributos são citados pelos entrevistados nas respostas das questões formuladas nas entrevistas realizadas.

\subsection{DisCUSSÃo ACERCA dA AVALIAÇÃO DOS ATORES}

\section{Categoria 1: Moradores da ZEIS Pina/Encanta-} MoçA

O Gráfico 1 destaca o valor social atribuído ao Parque dos Manguezais, tendo em vista as atividades de subsistência dos moradores da ZEIS Pina/Encanta-Moça que vivem dos insumos do ecossistema de manguezal (Figura 4):

Esse manguezal é importante porque beneficia muita família... gera uma renda e eles conseguem se sustentar...5

Rapaz, esse mangue eu acho que, se não fosse ele, a gente não tinha essas casas, não. Se olhar direitinho a madeira das casas...6

5 Homem, 24 anos, Autônomo, morador da comunidade há 8 anos.

6 Mulher, 36 anos, Pescadora, moradora da comunidade há 32 anos. 


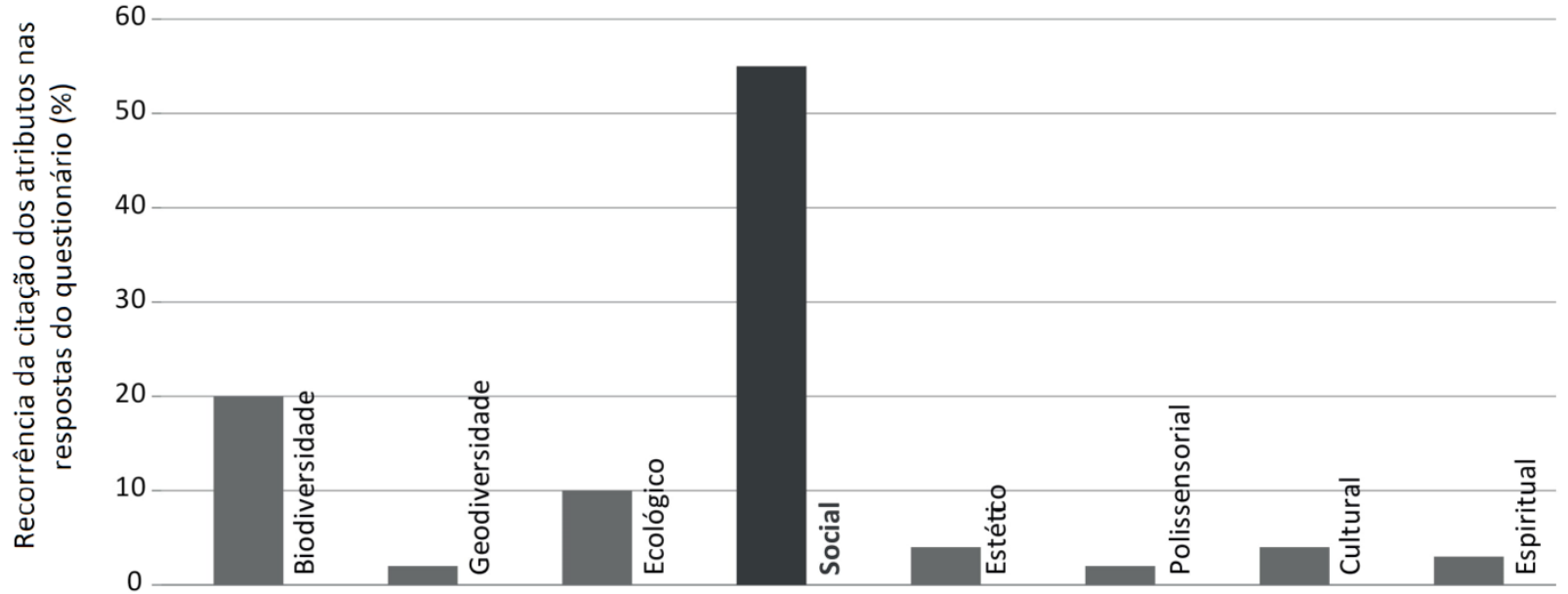

60

Gráfico 1 - Valores conferidos pelos moradores da ZEIS Pina/ Encanta-Moça a partir dos

atributos.

Fonte: Produzido pelos autores.

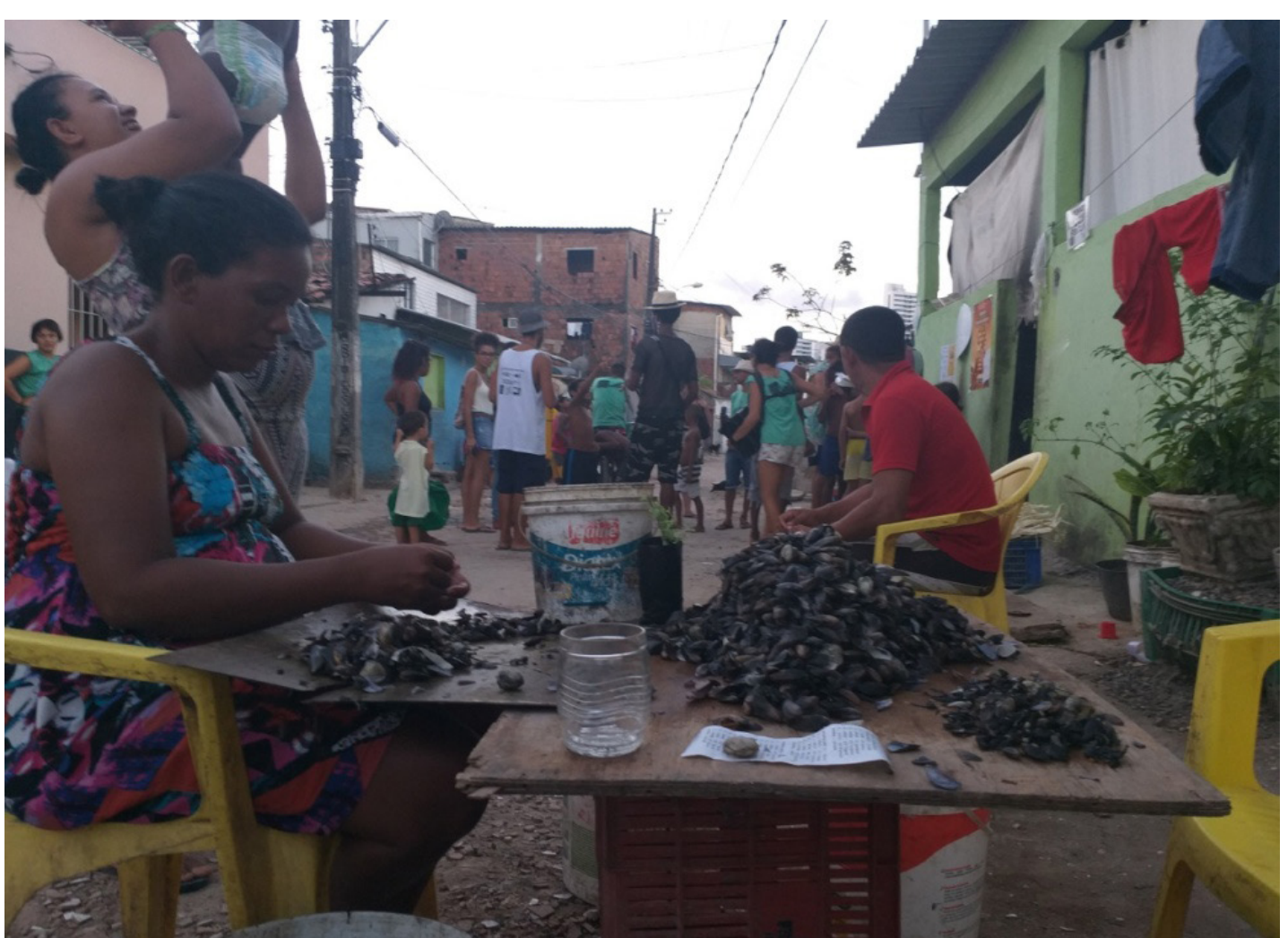


Essa avaliação também se aplica em relação ao valor de biodiversidade, caracterizado como o segundo valor atribuído pelos moradores da ZEIS. Apesar de remeter à importância ético-ambiental da manutenção dos organismos vivos e sua variabilidade (IUCN, 2002), no presente caso, a valoração da biodiversidade feita pelos moradores toma como referência as espécies de fauna e de flora, tendo como parâmetro seu valor comercial. A seguir, as falas exemplificam tal constatação:

(...) pegar alimento, né? Tem caranguejo, tem sururu... tudo é extraído do mangue. A sobrevivência da gente aqui de palafita é por conta do mangue?

Manguezal é tudo... é marisco, é sururu, é caranguejo. Mas, primeiro é marisco, o povo come ${ }^{8}$.

Os fragmentos de entrevistas acima revelam que, em se tratando do valor social e do valor de biodiversidade, muitos dos atributos citados remetem a ambos os valores. É importante destacar que, tendo em vista a biodiversidade, os moradores entrevistados relataram certo conhecimento e sensibilidade quanto à importância do ecossistema, confirmando seu valor ecológico. Ao compreender a importância ecológica, relacionam a biodiversidade não apenas à sua subsistência, como também à manutenção da vida do ecossistema. Em muitos momentos, pode-se dizer que essa consciência contribui para nortear suas ações extrativistas. Porém, sob outro ângulo, acontece de denunciarem a degradação do ecossistema pelos próprios moradores, revelando que, no seio da comunidade, as relações de conservação e degradação são controversas:

Pela comunidade o mangue é bem tratado, pois nós sobrevive dele. Quando nós tora uma árvore pra fazer as palafitas, nós faz por onde que tenha dois ou três galhos para que ele vingue. Quer dizer, nós não mata ele totalmente, só poda9

7 Ibidem.

8 Homem, 49 anos, Pescador e Ajudante de Pedreiro, morador da comunidade há um ano e meio.

9 Homem, 49 anos, Pescador e Ajudante de Pedreiro, morador da comunidade há um ano e meio
Eu sei que a comunidade está matando esse mangue, se você chegar de trás de onde eu moro, e olhar para a maré seca, você vai ver um bocado de sacola plástica, lixo. Antes, quando eu vim morar aqui, tinha uns peixinhos chamado barriga de tintim, tinha uns caranguejinhos chamado tesoura, umas paradinha, hoje não existe mais, entrou em extinção, não existe mais ${ }^{10}$.

Em relação a essa categoria de atores, os atributos de biodiversidade são destacados como valor central, a partir do qual os moradores determinam os demais valores. Para eles, o Parque dos Manguezais é compreendido em função da importância de suas espécies, principalmente da fauna, sendo a pesca papel fundamental na relação homem-natureza (Figura 5).

O valor estético e o valor polissensorial estão associados à vivência cotidiana dos moradores, que estão em contato direto com o ecossistema, por intermédio dos sentidos físicos e pela apreensão da paisagem. Creditam a experiência sensitiva ao "som das águas, dos pássaros, do vento nas árvores"11 e à sensação de encantamento ao vislumbrar, principalmente, a copa das árvores compondo o horizonte natural. Além disso, essa vivência destaca a relação com a história "patrimônio nosso"12 ou "lugar de cultura"13 (valor cultural), assim como as relações transcendentais que o Parque dos Manguezais evoca, enquanto criação e dádiva divina (valor espiritual).

10 Mulher, 43 anos, Pedreira, moradora da comunidade desde que nasceu. 11 Homem, 40 anos, Pescador, morador da comunidade desde que nasceu. 12 Homem, 24 anos, Autônomo, morador da comunidade há 8 anos.

13 Ibidem. 


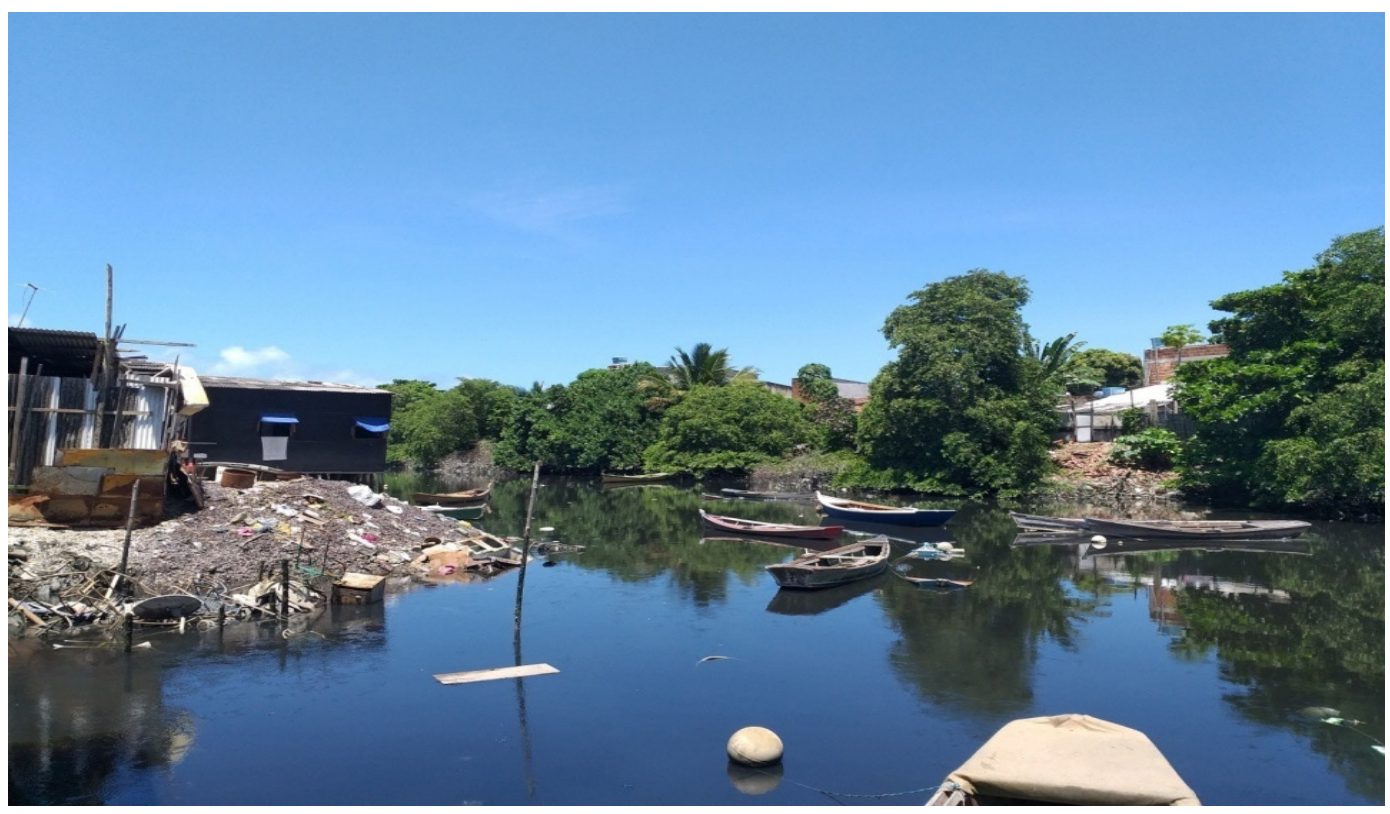

Figura 5 - Registro fotográfico com barcos pesqueiros nas bordas do manguezal. Fonte: Acervo dos autores, 2019.

\section{Categoria 2: Moradores de classe média}

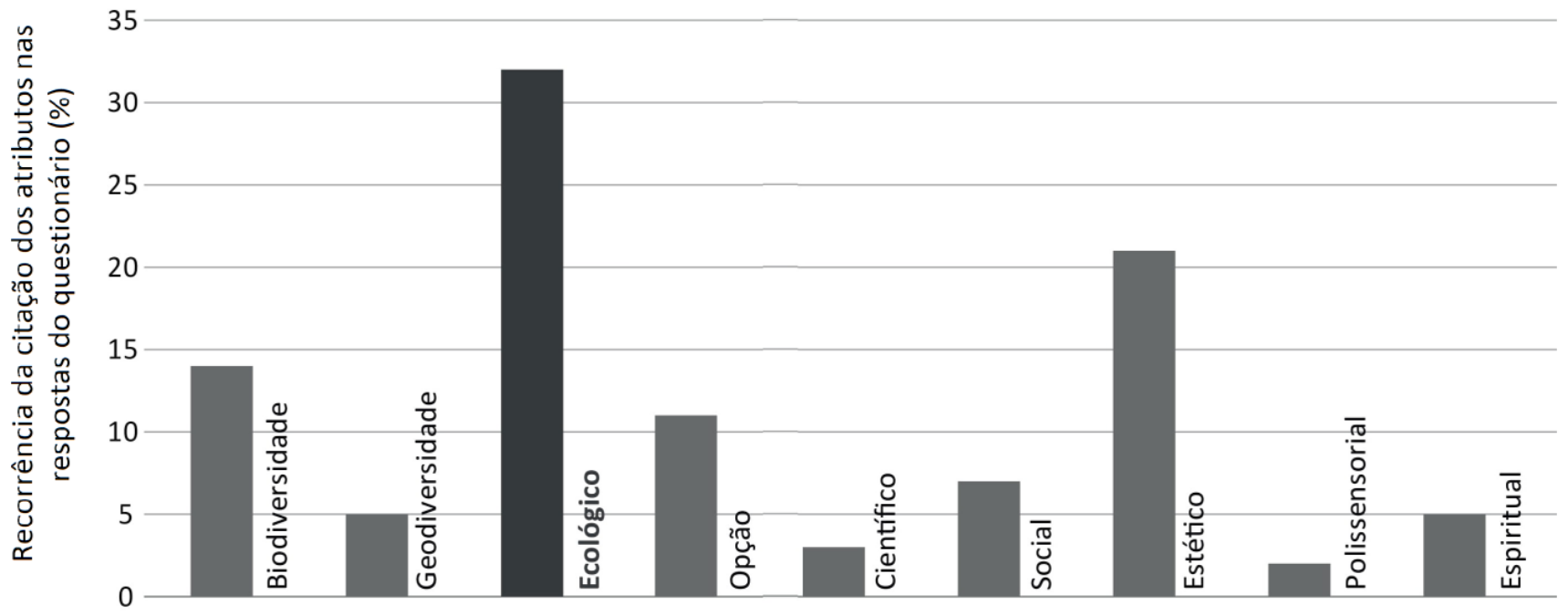

Gráfico 2 - Valores conferidos pelos moradores de classe-média a partir dos atributos. Fonte: Produzido pelos autores. 
Os moradores de classe média entrevistados são os que ocuparam o território do entorno do Parque dos Manguezais, principalmente após o ano de 2012, com a inauguração do Shopping RioMar, o maior centro de compras da cidade do Recife, que veio a impulsionar o mercado imobiliário local (SILVA et al., 2016). Tratando-se dessa categoria de atores, apesar de os locais de moradia estarem a pouco mais de $300 \mathrm{~m}$ da borda do Parque dos Manguezais, não existe uma relação direta entre tais atores e o ecossistema em si. Ao contrário, em todos os edifícios, construídos após a inauguração do Shopping, as varandas e janelas das áreas sociais e quartos estão voltadas para o lado oposto ao do Parque dos Manguezais (Figura 6).

A atitude dos promotores imobiliários e projetistas é de desdém, no que diz respeito ao Parque dos Manguezais. Observa-se que não há relação afetiva com a área nem interesse de usufruir as potencialidades paisagísticas que o Parque oferece. Em parte, essa atitude se explica pelo fato de que os habitantes são novos no bairro do Pina.

Muitas vezes, o valor ecológico do Parque dos Manguezais é destacado com base em um entendimento generalista sobre o meio natural, sem adentrar as questões específicas relacionadas aos principais elementos que caracterizam esse ecossistema. Tais aspectos podem ser observados nos depoimentos a seguir:

Sobre o Manguezal também não sei, não. É bom, faz parte. Faz parte do sistema... do ambiente ${ }^{14}$.

Contribuir diretamente para minha qualidade de vida, não sei... é equilíbrio ecológico, mas não sei se afeta meu dia a dia ${ }^{15}$.

Eu acho muito importante a parte de você manter o ecossistema funcionando ${ }^{16}$.

14 Mulher, 20 anos, Estudante, moradora do Pina há 2 anos.

15 Mulher, 39 anos, Enfermeira, moradora do Pina há 1 ano.

16 Mulher, 32 anos, Funcionária Pública, moradora do Pina há 3 anos.
Segundo os moradores, a compreensão da importância do ecossistema se deu após a inauguração da Via-Mangue. Trata-se de uma via expressa construída sobre as bordas do Parque dos Manguezais que resultou das demandas do bairro por infraestrutura viária (SILVA et al., 2016). A abertura da via permitiu uma linha de visada e um cenário nunca antes observado por essa população. Atualmente, o deslocamento em veículos por essa via representa um momento expressivo de experimentação da paisagem, permitindo que o valor estético seja reconhecido por essa categoria de atores, desde que a abertura da via descortinou a vista para o ecossistema, outrora enclausurado no tecido urbano da cidade (Figura 7).

A paisagem apreendida nesse lugar faz um contraponto com o tecido urbano adensado do bairro de Boa Viagem, e especificamente do Pina, onde se percebe um contraste na paisagem entre as tipologias do tecido urbano local, tradicionalmente consolidado, e as torres habitacionais e empresariais recentemente implantadas. Contudo, o caráter bucólico do manguezal ainda evoca sentimentos de fruição estética por parte desse grupo de moradores, como pode ser verificado nas declarações que se seguem:

Eu acho muito bonito, a gente acordar assim, visualmente, e ver o mangue, não ver um monte de prédio ${ }^{17}$.

Eu acho que ele é um respiro, eu gosto muito quando eu passo ali, na Via-Mangue, que eu observo o mangue... gosto sempre de observar essa região ${ }^{18}$.

Ao lado do valor estético, os moradores também destacam a geodiversidade e a bioversidade, enfatizando a interface que pode ser visualizada entre os elementos da natureza e a cidade, seja nos percursos, ao longo do sistema viário, seja através das janelas. A implantação das novas edificações, próximas a uma unidade de conservação, não implica a exclusão da biodiversidade no ambiente (Figura 8). Isso é o que destacam os moradores quando pontuam a presença da avifauna e de crustáceos que, espontaneamente, aparecem nas ruas e nas áreas molhadas dos arredores.

17 Mulher, 20 anos, Estudante, moradora do Pina há 2 anos.

18 Homem, 40 anos, Comunicador Social, morador do Pina há 3 anos e meio. 


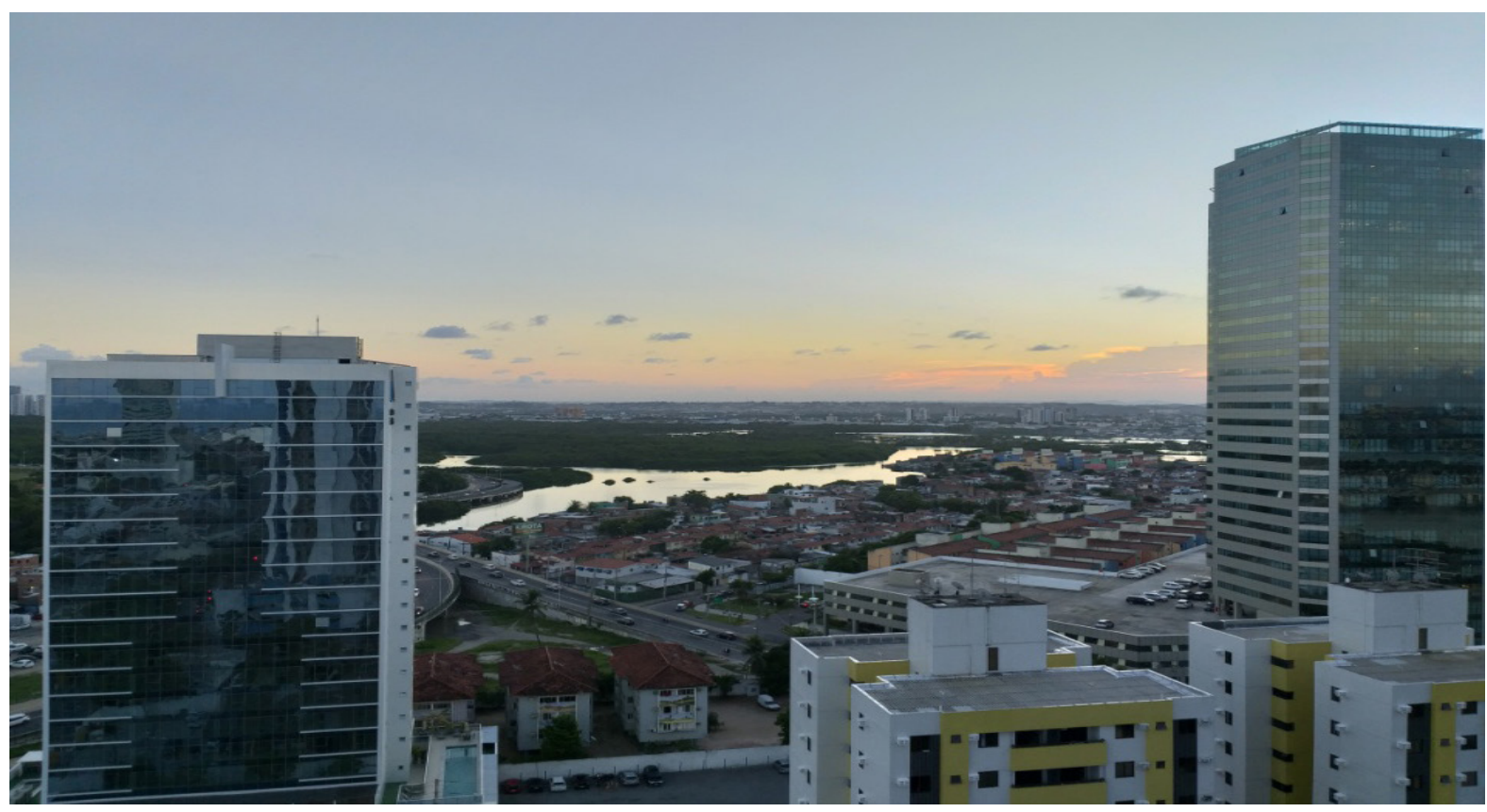

Figura 6 - Vista da janela de um dos edifícios do entorno do manguezal. Fonte: Acervo dos autores, cedido por morador do edifício, 2019.

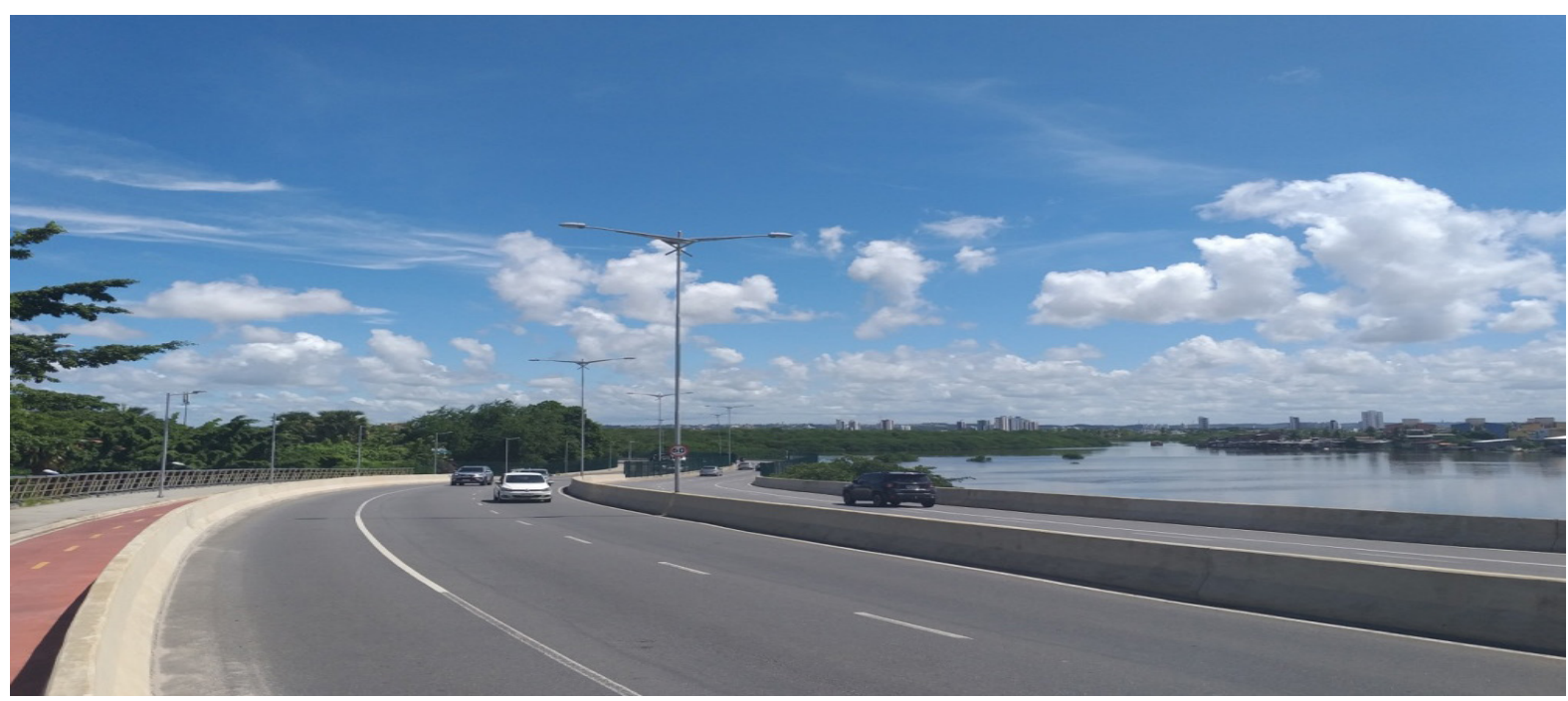

Figura 7 - Via-Mangue nas bordas do Manguezal.

Fonte: Acervo dos autores, 2019. 


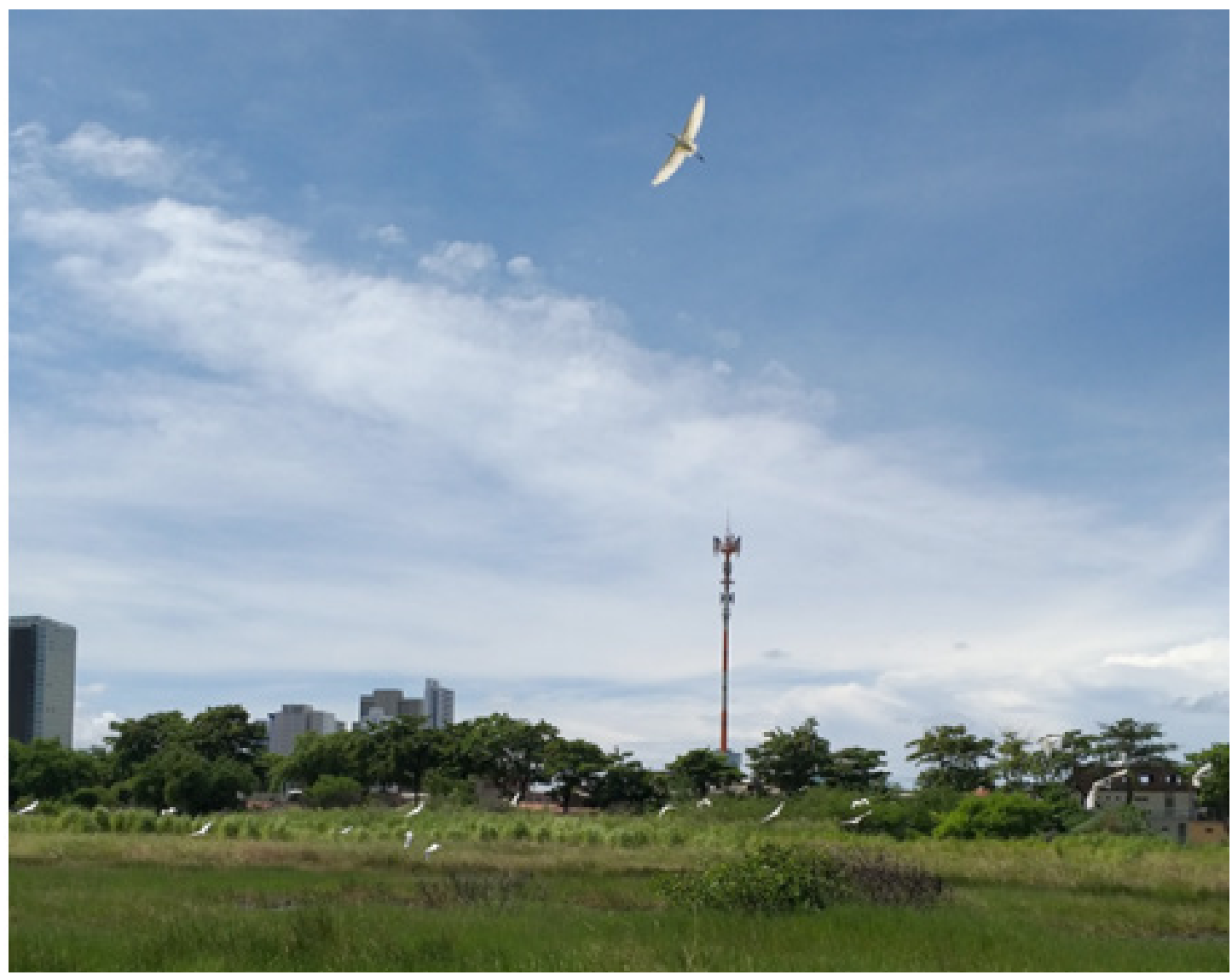

Figura 8 - Presença da avifauna local e aspectos gerais da paisagem do entorno da UC Parque dos Manguezais, onde se destacam no horizonte as edificações verticalizadas. Fonte: Acervo dos autores, 2019.

Outro aspecto levantado por essa categoria de atores são as potencialidades físico-naturais e socioambientais oferecidas pelo Manguezal. Apesar de não terem uma relação de dependência direta com o ecossistema, os moradores reconhecem sua importância para as comunidades do entorno, conferindo-Ihe um relevante valor social. Não obstante, essa categoria tende a interpretar as potencialidades oferecidas pelo Parque de forma sistêmica, relacionada com aspectos microclimáticos e de drenagem urbana, dentre outros. Apesar de reconhecerem a importância social do Parque, tendem a valorizar os aspectos de natureza físico-natural, tanto na escala macro quanto na escala urbana local, como pode ser verificado nas falas dos moradores, a seguir:
Rapaz, o manguezal, eu diria que é um espaço de contraposição desse ambiente da Zona Sul, de construção, de prédio em todo lugar, essa superpopulação nessa área desses dois bairros ${ }^{19}$.

Pra eles, servem para subsistência deles. E pra gente... não sei, principalmente a ventilação, eu morava ali mais perto do Manguezal e era bastante ventilado ${ }^{20}$.

Ele traz só benefícios em termos de circulação de ar, de diminuição da temperatura... eu acho aqui até bastante 19 Homem, 40 anos, Comunicador Social, morador do Pina há 3 anos e meio. 20 Mulher, 20 anos, Estudante, moradora do Pina há 2 anos. 
ventilado. E serve pras comunidades que moram ali e se utilizam do mangue pra sustento, né? ${ }^{21}$

A falta de relação de proximidade com o ecossistema também explica o fato de poucos atores dessa categoria destacarem os valores polissensorial e espiritual. Em paralelo, a falta de conhecimento mais aprofundado do Parque e do seu desempenho, enquanto laboratório biológico natural para a comunidade científica, justifica o porquê de poucos desses atores lhe conferirem valor científico. Ao reconhecer a importância ecológica e vislumbrar a paisagem descortinada pela Via-Mangue, esse grupo de atores sinaliza para possíveis usos voltados para atividades turísticas e de lazer. Daí justifica-se a atribuição do valor de opção ao ecossistema, fruto do reconhecimento das potencialidades físico-naturais e socioambientais que a Unidade de Conservação oferece.

\section{Categoria 3: Gestores públicos}

No que tange à visão dos gestores públicos, eles reconhecem o Manguezal como fonte de recursos para as comunidades ribeirinhas, remetendo ao valor social. Isso significa que, sob esse aspecto, a gestão pública da unidade de conservação está alinhada com determinados anseios imediatos da população residente. Nesse sentido, associam o valor social do Manguezal ao valor cultural, destacando as atividades de subsistência para a identidade local e urbana da cidade do Recife, conforme fragmento de entrevista:

Além da beleza de atributos ambientais, de equilíbrio, também, social, eu acho que a gente não pode excluir a questão de atributo social daquilo ali que é uma área muito significativa pra uma comunidade que historica-

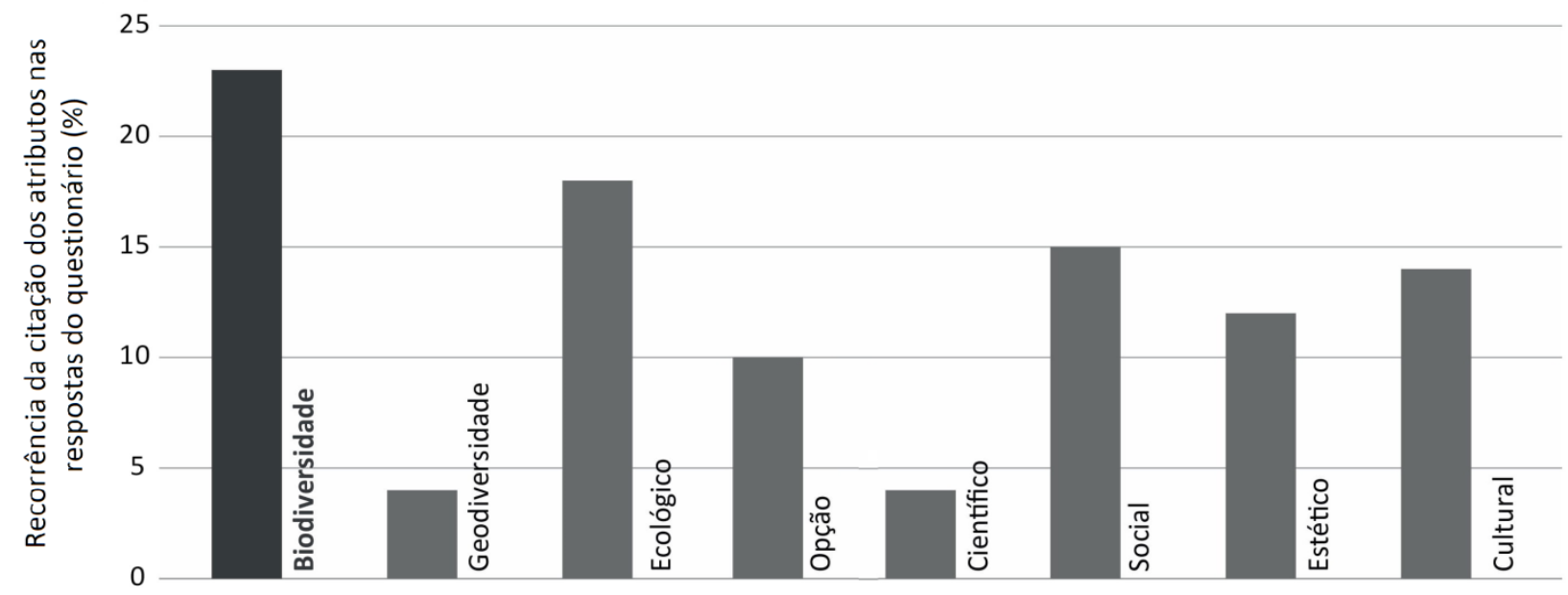

Gráfico 3 - Valores conferidos pelos gestores públicos a partir dos atributos. Fonte: Produzido pelos autores.

21 Mulher, 32 anos, Funcionária Pública, moradora do Pina há 3 anos. 
mente se instalou ali. E tem a parte de viver, gera renda aquilo ali, gera cultura, então acho que é significativo. Além do patrimônio ambiental, de todo valor intrínseco de diversidade, eu acho que tem um atributo social e econômico pra uma comunidade historicamente assentada ali muito grande. A história do Recife? Que surgiu no mangue, a história dos pescadores, é muito valor ${ }^{22}$.

Além disso, esses atores destacam que o Parque dos Manguezais desempenha um importante papel ambiental para a cidade, como um todo. Em relação às potencialidades físico-naturais e socioambientais oferecidas pelo ecossistema à cidade, foram destacadas questões relevantes para o equilíbrio ecológico da planície estuarina. As pessoas entrevistadas destacaram sua função hidrodinâmica para a cidade, considerando a presença do fragmento de natureza como esse fator de equilíbrio ambiental, o que confirma seu valor ecológico. Tais questões são enfatizadas nas declarações dos entrevistados:
(...) pra cidade do Recife eu enxergo a questão ambiental como mais importante... numa cidade como o Recife, com uma arborização escassa, esparsa, onde a principal vegetação nossa está exatamente nessas Unidades de Conservação, o que é aquilo ali pro equilíbrio hidrodinâmico da cidade, então a importância ambiental daquilo ali é gigantesca.... Imagine a retirada do Parque dos Manguezais, o impacto negativo inclusive de enchentes pra cidade ${ }^{23}$.

As Unidades de Conservação têm tanta importância ecológica quanto ambiental... Ecológica no sentido da conservação de fauna e flora tanto Stricto Sensu quanto Lato Sensu. E na questão ambiental, ele (o Parque) tem inúmeras importâncias, como a questão de criar um microclima, de reduzir o escoamento superficial de índices extremos de chuva e de criar uma sanidade ${ }^{24}$.

22 Mulher, Bióloga, Gestora Pública.

23 Mulher, Bióloga, Gestora Pública.

24 Homem, Engenheiro Florestal, Gestor Público.
Os entrevistados também destacaram o quanto a existência do Manguezal está atrelada à condição fisiográfica inicial da cidade do Recife. Fazendo um paralelo entre as espécies de mangue existentes na área e a paisagem original recifense, quando da ocupação portuguesa, pode-se associar a biodiversidade do ecossistema à identidade da cidade. Nesse sentido, a apreensão da paisagem evoca a biodiversidade e a geodiversidade, correlacionadas por sua vez com os aspectos estéticos e coma identidade cultural:

(...) é uma vegetação protegida, mesmo que ela tenha sido reconstruída, replantada, mas é uma vegetação de mangue nossa, é o que caracteriza nossa essência enquanto vegetação nativa, nossa cidade. Então é a questão mesmo de identidade cultural, a importância da nossa identidade, o que é aquela vegetação, a importância daquela vegetação, a importância biológica, ecológica daquela vegetação. E Cultural. Um patrimônio certamente nosso 25 .

É uma questão de honra até a gente como recifense ter aquilo ali. Porque é um marco da paisagem, um marco da história, o mangue é um marco da história do Recife, um marco na questão ambiental ${ }^{26}$.

Assim, para esses atores, observa-se que a biodiversidade do Parque dos Manguezais oferece serviços ecossistêmicos diversos que remontam à sua função ecológica para a cidade como um todo ou às questões relativas ao modo de vida das populações estabelecidas. Sobre essa categoria de atores, é importante destacar que os valores supracitados estão diretamente associados aos atributos de biodiversidade do bem patrimonial, sendo o valor de biodiversidade, portanto, o valor mais conferido.

25 Mulher, Bióloga, Gestora Pública.

26 Mulher, Arquiteta e Urbanista, Gestora Pública. 


\section{CAtegoria 4: Especialistas}

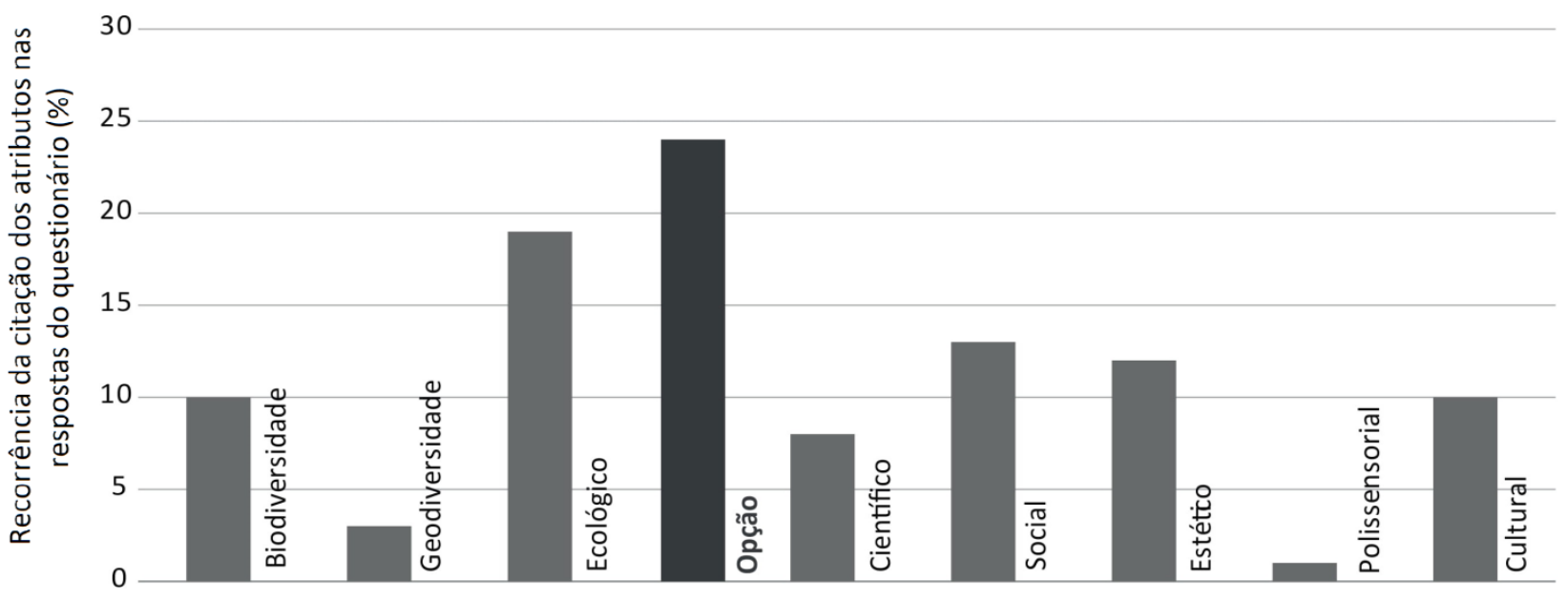

Gráfico 4: Valores conferidos pelos especialistas a partir dos atributos. Fonte: Produzido pelos autores.

A valorização do Parque dos Manguezais pelos especialistas entrevistados apresenta-se de forma diversa, uma vez que seus conhecimentos teóricos e empíricos estão ligados a cada ramo de atuação específica. De maneira geral, as pessoas entrevistadas tendem a observar e destacar a possibilidade de utilização futura do Parque dos Manguezais a depender das múltiplas funções que ele pode desempenhar para a cidade, como um todo, e do seu papel ecológico para as gerações presentes e futuras. Nesse sentido, o valor de opção e o valor ecológico são os mais destacados por esse grupo.

Primeiro, a gente precisa dos serviços do mangue. Por ser uma planície costeira, toda drenagem está atrelada ao mangue, então a gente não pode dissociar de jeito nenhum a existência dele dessa coisa prática. Ele é necessário para que a cidade funcione bem ${ }^{27}$.

27 Homem, Engenheiro Civil, Ambientalista e Pesquisador.
Ele (o manguezal) tem que ser protegido e instalar ali realmente o parque para que ele tenha vida, para que a comunidade usufrua dele, possa interagir com ele, compreender os seus significados ${ }^{28}$.

O turismo seria um viés para se explorar ali, um turismo mais pedagógico, não somente cultural. Acho que teria um grande potencial para um turismo Técnico Científico 29 .

Assim como nas entrevistas com os gestores, também foi destacada a condição do Parque dos Manguezais enquanto remanescente do passado estuarino do Recife. Para esses atores, o Parque representa um registro vivo da história da fisiografia da cidade do Recife, apresentando testemunhos da biodiversidade nativa, além de elementos fisiográficos, como as águas que remetem à 28 Homem, Engenheiro Civil, Professor Universitário e Pesquisador. 29 Homem, Arquiteto e Urbanista, Gestor de Patrimônio Cultural. 
identidade ambiental da cidade. Os valores atribuídos por essa categoria de atores estão relacionados à biodiversidade e à geodiversidade que, por sua vez, remetem ao valor estético e ao valor cultural do manguezal:

Do ponto de vista paisagístico, ele (o manguezal) tem uma importância muito grande para cidade do Recife, quase como um registro do que seria a cidade há séculos passados, pois, grande parte dela foi construída sobre aterros e aí, talvez, seja um registro dessa conformação mais original dessa cidade $^{30}$.

É um dos vestígios de um meio pré-existente à ocupação do Recife. Sabemos que o Recife foi construído num grande estuário inundável, tudo que veio em consequência foi aterro, então, sob esse aspecto, é importantíssimo segurar ainda aquela zona, que foi um resquício desse meio natural que precedeu a ocupação ${ }^{31}$.

\section{Considerações Sobre os Valores Atribuídos ao Manguezal}

Considerando os atores como o foco das discussões, pode-se destacar as peculiaridades que marcam a percepção de cada grupo sobre os atributos do Parque dos Manguezais e a forma como lhe conferem valores. Nesse sentido, as relações de vivência norteiam as perspectivas da população sobre o ambiente. Consequentemente, os valores atribuídos serão relacionados com essa perspectiva e dinâmica (MOURA et al., 2018).

Bezerra (2018) pontua que tais valores são atribuídos pelos homens à natureza não dissociados da "essência de suas ações e atitudes em relação aos processos naturais e do meio onde vivem" (p. 55). Segundo a autora, isso enfatiza a dimensão antropocêntrica, na medida em que a natureza é percebida como fornecedora de insumos e meio de subsistência para o homem. Tais

30 Homem, Arquiteto e Urbanista, Gestor de Patrimônio Cultural.

31 Homem, Arquiteto e Urbanista, Professor Universitário e Pesquisador. reflexões estão relacionadas, como que destaca Quintão (1984) quando trata da relação do homem com a natureza, em cuja essência reside o caráter utilitarista e antropocêntrico:

As crianças brasileiras iniciam seu contato com a natureza através das estórias e crendices, e usam a atiradeira como primeiro instrumento de dominação sobre os recursos naturais. Com a morte de pequenos pássaros, a criança percebe que a natureza é frágil, podendo ser facilmente dominada. Esse tipo de relação tende a aprofundar-se, gerando posteriormente uma relação de utilitarismo imediatista com a flora, a fauna e os outros recursos naturais (p. 52).

Sob essa ótica, os valores são atribuídos não apenas pela dinâmica social, propriamente dita, mas como fruto de um processo mais profundo que traz à tona a relação de dominação, simbiose e identificação do homem com a natureza. Ou seja, após a compilação de todos os valores, o valor social é o mais enfatizado pelos entrevistados. Tal constatação é vista no gráfico 5 .

A discussão sobre a perspectiva antropocêntrica da relação entre o homem e o meio natural, aqui levantada, não deve induzir à generalização dos valores atribuídos. Todos os entes fazem parte de uma totalidade, composta por percepções multifacetadas do patrimônio natural. Tais percepções remetem à essência do bem patrimonial que, por sua vez, é composto por atributos culturais e naturais, inter-relacionados e em constante dinâmica. As percepções dos atores, traduzidas pelos valores atribuídos, determinam a significância do Parque dos Manguezais. Não obstante, admite-se que muitos dos valores podem se tornar conflitantes, ou em desacordo com as perspectivas tradicionais adotadas pela gestão (MASON, 2004). 
Gráfico 5 - Síntese dos valores conferidos por todos os atores entrevistados a partir dos atributos.

Fonte: Produzido pelos autores.

\section{CONCLUSÃO}

Tendo em vista que o Parque dos Manguezais constitui um Patrimônio Natural Urbano da cidade do Recife, com suas devidas particularidades, a identificação dos valores que lhe são atribuídos por atores das mais distintas categorias representa uma importante base teórico-metodológica para a elaboração dos Planos de Gestão da Conservação e manejo da área.

No contexto urbano, tal discussão se faz urgente, na medida em que pode alcançar proporções complexas, visto que o meio ambiente natural se torna não só localidade para estabelecimento de moradias, como também desempenha uma função utilitarista de grande impacto ao prover o homem dos insumos necessários à sua sobrevivência.

A dissociação do Homem em relação à Natureza, na cidade, não faz sentido quando se trata daqueles que convivem diretamente com os ecossistemas inseridos no contexto urbano. Esses singulares fragmentos ecossistêmicos, que resistem à ocupação humana, constituem importantes remanescentes naturais cujo papel é fundamental para a manutenção do equilíbrio ecológico urbano. Nesse sentido, além de atributos naturais, dado seu valor de existência, ligados à função ambiental, as comunidades atribuem valores culturais imbricados aos ecossistemas. No Parque dos
Manguezais, tais valores conferem relevante importância sociocultural à Unidade de Conservação, no contexto da cidade, cuja compreensão é substancial para quaisquer intervenções urbanas, seja na Unidade em si, seja nas comunidades próximas.

Assim, o Patrimônio Natural em meio urbano desponta como um bem carregado de atributos e valores que lhe conferem uma significância híbrida. Portanto, a significância do Parque dos Manguezais, analisada e discutida no presente artigo, deve ser reconhecida coletivamente por todos os atores que participam, direta ou indiretamente, da dinâmica social, cultural e de gestão do ambiente urbano e ambiental da unidade protegida e do seu entorno. Tanto os processos de apreensão dos valores junto aos atores quanto de validação dos resultados obtidos devem passar pela aprovação e reconhecimento de toda a comunidade que interage com o bem. Em quaisquer estudos, análises e elaboração de planos ou projetos urbanos estratégicos que tenham como objetivo a Conservação Patrimonial dos bens naturais, como é o caso do Parque dos Manguezais, é indispensável que sejam considerados diversos olhares, inclusive o das comunidades de baixa renda, envolvidas no dia-a-dia com o bem.

Ao se propor a participação das Comunidades do Bode, do Encanta-Moça, do Jardim Beira-Rio, além dos recentes moradores 
que se somam à história do Bairro do Pina, no estudo do bem patrimonial, toca-se na questão crucial da gestão pública. Em outras palavras, todos esses atores estão envolvidos na relação entre a cidade e os ecossistemas. Por fim, destaca-se que os valores são contingentes e mudam ao longo do tempo. Assim sendo, a cada momento há que se avaliar e qualificar os valores atribuídos pelos atores, atuais e futuros.

\section{ReferênCIAS Bibliográficas}

BARDIN, Laurence. Análise de Conteúdo. Lisboa: Editora 70, 1977. 225p.

BEZERRA, Onilda Gomes. A Conservação do Patrimônio Natural/Cultural: Um sistem de indicadores para o monitoramento da conservação da significância dos Parques Nacionais brasileiros Patrimônios da Humanidade. 2011. 359 f. Tese (Doutorado em Desenvolvimento Urbano) - Universidade Federal de Pernambuco, Recife, 2011.

BEZERRA, Onilda Gomes. Paisagem como totalidade Homem-Natureza. In: VERAS, Lúcia, et al. Cadernos de Arquitetura e Urbanismo, v.2. João Pessoa: Patmos Editora, 2017. p. 34-51.

BEZERRA, Onilda Gomes. O patrimônio natural no contexto da conservação integrada.Revista Patrimônio e Memória. São Paulo: UNESP, v. 14, n. 1, p. 51-68, 2018.

DIEGUES, Antônio Carlos. O Mito Moderno da Natureza Intocada. São Paulo: Editora Hucitec, 1996. 163p.

FUNDAÇ̃̃O SOS MATA ATLÂNTICA. Relatório anual de atividades. São Paulo: [s.n.], 2017.

FUNDAÇÃO SOS MATA ATLÂNTICA; INSTITUTO NACIONAL DE PESQUISAS ESPACIAIS. Atlas dos remanescentes florestais de mata atlântica período 2018-2019. São Paulo: [s.n.], 2020.

ICOMOS. The Burra Charter. Burra: Australia ICOMOS, 2013

INSTITUTO CHICO MENDES DE CONSERVAÇÃO DA BIODIVERSIDADE. Atlas dos Manguezais do Brasil. Brasília: [s.n.], 2018.

IUCN Red List of Threatened Species. IUCN Red List, 2018. Disponível em: <https:// www.iucnredlist.org/>. Acesso em: 25 fev. 2019.

IUCN. Australian Natural Heritage Charter, second edition. Sidney NSW: Australian Heritage Commission, 2002.

LACERDA, Norma. Valores dos Bens Patrimoniais. In: LACERDA, Norma; ZANCHETI, Sílvio Mendes. Plano da Gestão da Conservação Urbana: Conceitos e Métodos. Recife: $\mathrm{CECl}$, 2012. p. 44-54.

MASON, Randall. Fixing Historic Preservation: A Constructive Critique of "Significance". Places, a Forum of Environmental Design, v. 16, n. 1, p. 64-71, 2004

MELO, José Gustavo da Silva. Registro das dinâmicas espaciais dos manguezais do baixo curso do Capibaribe. 2014. 124 f. Dissertação (Mestrado em Desenvolvimento Urbano) - Universidade Federal de Pernambuco, Recife, 2014.

MORA, Luís de la. A Gestão da Conservação do Patrimônio e seus Instrumentos. In
LACERDA, Norma; ZANCHETI, Sílvio Mendes. Plano de Gestão da Conservação Urbana: Conceitos e Métodos. Recife: $\mathrm{CECl}$, 2012. p. 114-125.

MOURA, Célio Henrique Rocha; BEZERRA, Onilda Gomes; SILVA, Joelmir Marques. Os Valores Naturais das Unidades de Conservação do Recife: Mata de Dois Irmãos Mata do Engenho Uchôa. Revista Percurso. Maringá: UEM, v. 10, p. 131-155, 2018.

OUINTÃO, Ângela Tresinari Bernardes. Utilitarismo versus ética ecológica. Revista do Patrimônio Histórico e Artístico Nacional. Brasília: IPHAN, n. 19, p.49-52, 1984.

RECIFE. Lei Municipal $n^{\circ} 16.176$, de 9 de abril de 1996. Estabelece a Lei de Uso e Ocupação do Solo do Recife.

RECIFE. Lei Municipal no 17.511 , de 29 de dezembro de 2008. Promove a revisão do Plano Diretor do município do Recife.

RECIFE. Decreto $n^{\circ} 25.565$, de 1 de dezembro de 2010. Regulamenta a Unidade Protegida Parque dos Manguezais.

RECIFE. Lei Municipal $n^{\circ} 18.014$, de 10 de maio de 2014. Institui o Sistema Municipal de Unidades Protegidas - SMUP Recife e dá outras providências.

RIBEIRO, Cecília; LIRA, Flaviana. Autenticidade, Integridade e Significância Cultural.

In: LACERDA, Norma; ZANCHETI, Sílvio Mendes. Plano de Gestão da Conservação Urbana: Conceitos e Métodos. Recife: CECl, 2012. p. 32-41.

SILVA, Júlio César Felix; GOMES, Edvânia Torres Aquiar; ALBUQUERQUE, Mariana Zerbone Alves. A Cidade: Uma leitura Geográfica da Paisagem Urbana da metrópole pelo Pina, Recife - PE. Revista Movimentos Sociais e Dinâmicas Espaciais. Recife: UFPE, v, 5, p. 55-73, 2016 
Célio Henrique Rocha Moura

Universidade Federal de Pernambuco, (UFPE). Programa de Pós-

graduação em Desenvolvimento Urbano (MDU)

Avenida da Arquitetura, s/n, Cidade Universitária, Recife - PE, Brasil.

50740-550

https://orcid.org/0000-0003-2510-6314

celiohrocha@gmail.com

\section{Onilda Gomes Bezerra}

Universidade Federal de Pernambuco (UFPE), Departamento de

Arquitetura e Urbanismo (DAU).

Avenida da Arquitetura, s/n, Cidade Universitária, Recife - PE, Brasil.

50740-550

https://orcid.org/0000-0003-0020-046X

onibezerra@yahoo.com.br

Tomás de Albuquerque Lapa

Universidade Federal de Pernambuco (UFPE), Programa de

Pós-graduação em Desenvolvimento Urbano (MDU).

Avenida da Arquitetura, s/n, Cidade Universitária, Recife - PE, Brasil.

50740-550

https://orcid.org/0000-0003-1763-1004

thlapa@outlook.com.br

Caio Coelho Silva Albuquerque

Universidade Federal de Pernambuco (UFPE), Programa de

Pós-graduação em Desenvolvimento Urbano (MDU).

Avenida da Arquitetura, s/n, Cidade Universitária, Recife - PE, Brasil.

50740-550

https://orcid.org/0000-0002-5866-0728

caiocsalbuquerque@gmail.com

Nota do Editor:

Submetido em: 22/10/2020

Aprovado em: 09/03/2021

Revisão: RMO 